\title{
The economics of REDD through an incidence of burdens and benefits lens
}

Article

Accepted Version

Robinson, E. J. Z., Somerville, S. and Albers, H. J. (2019) The economics of REDD through an incidence of burdens and benefits lens. International Review of Environmental and Resource Economics, 13 (1-2). pp. 165-202. ISSN 1932-1473 doi: https://doi.org/10.1561/101.00000108 Available at https://centaur.reading.ac.uk/83449/

It is advisable to refer to the publisher's version if you intend to cite from the work. See Guidance on citing.

To link to this article DOI: http://dx.doi.org/10.1561/101.00000108

Publisher: NOW

All outputs in CentAUR are protected by Intellectual Property Rights law, including copyright law. Copyright and IPR is retained by the creators or other copyright holders. Terms and conditions for use of this material are defined in the End User Agreement.

\section{www.reading.ac.uk/centaur}

\section{CentAUR}

Central Archive at the University of Reading 
Reading's research outputs online 


\title{
Climate change and the economics of REDD through an efficiency-equity lens
}

\author{
E J Z Robinson, S Somerville, H J Albers
}

\section{Introduction}

Though REDD, "reduced emissions from deforestation and forest degradation", has promised much for climate change mitigation, for forests, and for lower-income countries, criticisms of the incentive mechanisms in a context of ill-defined property rights and the incidence of burdens and benefits abound. Indeed, a recent article has suggested that "furtive whispers ... REDD+ is dead..." (Fletcher et al., 2016). REDD has proven complicated, costly to implement, controversial, and arguably ineffective in achieving its aims of reducing GHG emissions (Dyer and Counsell, 2010). The distributional impact of REDD is increasingly voiced as a concern: who benefits and who is harmed by the introduction of a REDD initiative; who dictates the "rules of the game"; who has the rights to sequestered carbon and thus to REDD payments.

In this review article we explore REDD through an economics lens. We highlight how the literature has evolved in parallel with the evolution of REDD. We start with a brief description of the genesis of REDD, its underlying rationale, and its origins in payments for economic services; address the need for rigorous, and therefore costly, monitoring, reporting and verification; discuss the literature that evaluates REDD initiatives; and review the arguments around issues of equity and climate justice as they complicate REDD implementation and effectiveness.

REDD is controversial. As a market-based approach REDD continues to be questioned (e.g. Corbera, 2012; Redford et al., 2013; Boucher, 2015) within the broader discussion of whether market-based conservation has a future (Fletcher et al., 2016). Whilst some see market-based funding through carbon markets as a low-cost approach to reducing emissions, others see such offsetting as flawed, and object to the commodification and marketization of standing forests. Indeed, market mechanisms have been condemned by some, including the "climate justice" movement. The Bolivia UNFCC submission explicitly condemned market mechanisms, including REDD (Long et al., 2010). A growing literature addresses REDD in the context of climate justice that expresses concerns, for example, as to whether market-based approaches will benefit more powerful groups and harm indigenous forest-dependent peoples (Okereke and Dooley, 2010). While we are aware of the importance of these debates, here we address equity and efficiency considerations as related to the economics of REDD.

The efficiency aspects of REDD include the gains in cost-effectiveness from unleashing the power of markets to solve the problem of under-provision of the public good of carbon sequestration. Among other things, those gains rely on the ability to fully define property rights and legal institutions to allow the markets to function well. Creating 
markets for public goods always proves challenging. The difficulties are compounded in the LIMC context of complex but often incomplete institutions to support such markets. Further, in keeping with an economics perspective, this review article addressing issues of equity. We consider the impact both on and of REDD implementation with respect to the distribution of benefits and costs across countries, across institutions within countries, and across individuals; the role of compensation versus incentive; and ancillary benefits from REDD including pro-poor versions of implementation.

In all, over 300 REDD projects have been implemented in 64 countries under the United Nations REDD Pogramme (Sills et al., 2014; Rakatama et al, 2017). They have been implemented in many different ways, reflecting differences in forest governance and ownership, and government preferences. As we write, we recognize that there are many review articles (for example, Agrawal et al., 2011; Albers and Robinson, 2013) and books (for example, Angelsen, 2008b and 2009) addressing REDD, some of them quite recent. Our aim is not to replicate, but rather to provide a different perspective on the economics of REDD in the literature.

We first address the origins of REDD, including its conceptualization as an international payment for ecosystem services. We then consider how the implementation of REDD has been influenced by a myriad of practical realities that are often intertwined. These include issues of property rights and land tenure; the high costs of setting up, monitoring, and enforcing REDD rules and regulations; and how the costs and benefits associated with REDD are distributed.

\section{Bringing LMICs into Climate Policy Through Payments for Ecosystem Services}

REDD was originally conceived as a classic PES - a payment for the ecosystem service of avoided forest loss. Through subsequent agreements and then through implementation, that conception has changed in reaction to aspects of the settings that complicate market-based mechanisms, the realization of higher than expected costs, and a broadening of the goals of REDD including the provision of ancillary benefits for biodiversity and/or poverty alleviation.

\subsection{Origins of REDD}

At the third Conference of the Parties (COP) in Kyoto, 1997, higher-income countries committed to reducing greenhouse gas (GHG) emissions by setting binding targets for "Annex 1 countries" - the 37 industrialised countries and the European community (Babiker et al., 2000). The Clean Development Mechanism, CDM, established under the Kyoto protocol and entered into force in 2005, allowed Annex 1 countries to achieve compliance with the UNFCCC (United Nations Framework Convention on Climate Change) by paying for the reduction of emissions in non-Annex 1 (lower-income) countries (UNFCC, 1997; Oberthür and Ott, 1999; Shrestha and Timilsina, 2002). Increasing forest cover through afforestation and reforestation in lower-income countries was eligible for carbon credits through the CDM. Thus lower-income countries and their forests were brought formally into international climate talks and climate 
action only as the providers of carbon storage benefits to offset emissions in other countries.

At the time that the CDM was proposed, forest loss was estimated to be contributing to around one quarter of global GHG emissions (Neeff and Ascui, 2009). ${ }^{1}$ Yet, avoided forest loss was not accommodated in the CDM (Pedroni et al., 2009). The possibility of payments for reducing forest loss, as opposed to payments for increasing forest cover as covered by the CDM, was added during the 2007 Bali climate change meetings (Agrawal et al., 2011, provide considerable detail). Costa Rica and Papua New Guinea proposed that lower-income countries should be rewarded through financial compensation for reducing their rates of deforestation relative to a baseline rate (Pedroni et al., 2009; Buizer et al., 2014). Such avoided forest loss was incorporated first through RED, reduced emissions from deforestation, and its later manifestation REDD, reduced emissions from deforestation and forest degradation. A “+” was added, REDD+, which expanded the concept of REDD to encompass considerations of conservation, sustainable forest management, and afforestation and reforestation (Albers and Robinson, 2013), referred to post Copenhagen COP 15 as "Reducing emissions from deforestation and forest degradation and the role of conservation, sustainable management of forests and enhancement of forest carbon stocks in developing countries" (Cadman et al., 2017).

REDD provides an opportunity for LIMCs that have ongoing forest loss to participate in climate policy and agreements in a direct manner, rather than indirectly as through CDM. The motivations for REDD included a sense that avoided forest loss might provide carbon sequestration in a less expensive - more efficient - manner than other mechanisms. In addition, one goal of REDD was to enable more countries to contribute to climate solutions, reflecting an equity consideration at the country level. Not only might those countries be more integrated into climate policy decisions, but they could potentially capture global values for emissions reductions as financial gains. REDD can therefore be conceptualized as a policy mechanism that could not avoid issues of efficiency and equity, even where they are not discussed explicitly.

\subsection{Economic underpinnings of REDD as a payment for ecosystem services}

Trees sequester carbon dioxide while growing, and thus can play an important role in mitigating climate change, providing an ecosystem service - carbon sequestration - that historically has not passed through markets and that is not paid for by the beneficiaries of the service. The Kyoto protocol, through CDM and then REDD, provided an incentivebased mechanism for the value of this carbon sequestration, a global public good, to be realized by the owners of tropical forests CDM and REDD are both based on the relatively straight forward economic principle that private incentives to deforest and degrade forests can be aligned with the social optimum through a relevant payment for the ecosystem service of carbon sequestration. As a PES, REDD payments are conditionally based on the amount of forest loss avoided due to changes in land use

1 That number has fallen considerably over the past two decades to somewhere between 12 and $17 \%$ (Van de Werf et al., 2009) as the rate of forest loss has fallen and total GHG emissions increased. 
behavior. The promise of the payment creates an incentive for that changed behavior of lower forest use.

In this vein, much of the earlier economics literature conceptualised REDD as an international payment for ecosystem services in which the service provided was carbon sequestration in natural forests. Those payments are meant to incentivize additional carbon storage that would not have occurred without the payment due to forest loss, whether deforestation or degradation (detailed discussions in Wunder, 2009; Pagiola, 2011). The role of markets was highlighted in enabling lower-income countries to realise the public good value of their natural forests. Indeed, REDD has been described as "the world's largest PES experiment" (Corbera, 2012: p612), implying a role for market transactions, and the commodification of forest ecosystem services, specifically carbon sequestration. Such a "neoliberal conservation" narrative can be found, for example, in REDD discussions in Brazil (van der Hoff et al., 2015).

Theoretically, a PES involves a voluntary agreement between the owner of a service and the buyer of a service (Wunder, 2005). As an example, a private landowner chooses whether to keep land as forest or to convert it, perhaps to agricultural land. If the privately optimal choice is to deforest, but the socially optimal choice is not, then a REDD payment can provide sufficient incentive for the landowner to find it optimal not to deforest. Palmer et al. (2017) provide a classic model of REDD as a voluntary PES between an individual private landowner and the government, calibrating their model to Acre state in Brazil. The government will offer a REDD payment just large enough that the landowner chooses to keep their land as forest rather than convert to the more privately choice of agriculture, but only if that REDD payment is lower than the value of the additional carbon sequestration due to the avoided conversion. For the private landowner, the REDD payment needs to be just sufficient to make forest conservation more profitable than agricultural production. REDD as a PES therefore offers a win-win outcome for forest landowners and climate change mitigation (Angelsen et al., 2012). As such, the REDD payment is an incentive to provide the public good, with that incentive being large enough to offset the foregone benefits of the next best land use.

\subsection{The realities of REDD as a PES}

Where "landownership and carbon rights coincide", the implementation of REDD is relatively straight forward (Corbera et al., 2011: p302). For example, in Costa Rica, private ownership of forests stood at $55 \%$ of all forested area in 2005 . The country has strongly supported a PES-oriented approach to REDD, and initially required REDD to be undertaken only where there is formal title to the forestland (Corbera et al., 2011). Indeed, a number of examples, particularly in Latin American countries, follow this modality of REDD implementation fairly closely, in part because a relatively large share of forest land is owned by individuals. Even with ownership, however, landowners engaged in a PES may incur property rights enforcement costs to prevent forest degradation by other people, and those costs may prove high enough to push up the necessary payment or to cause potential PES participants to drop out (Alix-Garcia, Shapiro, and Sims, 2012). 
Although the conceptualisation of REDD as a voluntary PES is elegant, it does not reflect the reality of much of the forest loss that occurs in many lower-income country settings, whether deforestation or forest degradation. For example, African governments claim tenure for over 94\% of forested land (Romano and Reeb, 2008; Sunderlin et al., 2008; Rights and Resource Initiative, 2013). Forest loss often occurs due to neglect of a forest by the government landowner rather than any active land use choice. Instead, it is the outcome of the uncoordinated actions of many individuals with no de jure ownership rights to the land. These people have no rights to convert the forest to agricultural land, or to harvest timber and non-timber products, which means they have no rights or authority to prevent such activities nor to capture REDD payments.

The complexities of forest governance and forest usage - who owns the forests, who uses the forests, and who takes responsibility for the forests - have proven central to how REDD has been implemented and how it has evolved since it was first mooted. For example, the government may own the natural forest though neglect to manage it; nearby villagers may depend on the forest for their livelihoods, though any extraction is de jure illegal; these villagers may have a clear incentive to protect the forest but no mandate or authority; and outsiders may extract timber from, or produce charcoal in, the forest but have no stake in any REDD scheme (Robinson et al., 2014). In such a situation, who has rights to the carbon, who has rights to incentive payments, and how any REDD scheme is enforced are complex issues that must be resolved before a REDD project is implemented. These complexities influence all aspects of REDD implementation, from monitoring and verification, through to funding mechanisms, and including how payments are shared amongst communities. These realities and complexities limit the broad application of REDD as a pure PES, and have led to modifications in REDD's goals, implementation, and concept as a PES. In the following sections we explore these aspects of REDD, focusing on how they have been addressed in the economics literature, and in particular their implications for equity and efficiency.

\section{The costs, benefits, and funding of REDD}

In a voluntary PES scheme, the benefits of introducing a market for a particular ecosystem service must outweigh the costs or the transaction will not occur. Similarly for REDD, the original point of the initiative was to provide a lower-cost approach to mitigating climate change through reducing the rate of forest loss in lower-income countries. The earlier REDD literature identifies and estimates the costs of implementing REDD relative to the benefits. Two key conclusions of the literature are that the full costs of REDD were under-estimated when REDD was first mooted; and determining who receives payments and who bears the burdens from REDD is much less simple than in a classic PES between one buyer and one seller of the environmental service.

\subsection{REDD costs}

One of the reasons that forest loss was not included in the 1998 Kyoto Protocol was the recognition of how difficult (and implicitly how costly) monitoring, reporting, and verifying forest loss is, particularly when the measurement is against an unobservable 
counterfactual pathway (Long et al., 2011; see Lederer, 2011, for a detailed comparison of the costs and modalities of REDD versus CDM implementation). Despite decades of evidence that slowing deforestation proves difficult, some of the initial literature (for example, Stern, 2007; Eliasch, 2008) suggested that REDD would be a "low-cost, rapidwin solution" for climate change mitigation (Lund et al., 2017). Similarly, McKinsey and Company's "Global Greenhouse Gas Abatement Cost Curve" suggested that REDD was a relatively low cost approach to reducing emissions, a "low hanging fruit". Many such studies underestimated or ignored several categories of costs including: REDDreadiness costs that establish the foundation for REDD to operate, often incorporating the costs of defining and establishing property rights; opportunity costs that reflect economic and cultural values for land beyond the oft-used agricultural values; and ongoing costs including monitoring and enforcement costs in LIMC settings. When all the costs are included, REDD has been found not to be a low-cost approach to climate change mitigation, but, instead, rather costly and imperfect.

\section{$R E D D$ readiness}

If REDD represents a market contract between buyers and sellers of carbon credits, then rights to carbon must be well defined, and proper measurement is essential. Such measurement must include an inventory of carbon stocks, a methodology for determining the likely trajectory of forest loss without any REDD initiative - the counterfactual, in addition to the rate of forest loss with the initiative. Therefore in the early stages of REDD design and implementation, as reflected in the literature, considerable attention was paid to countries being in a position to accept REDD funding in exchange for a verified reduction in forest-based emissions relative to a measurable and verifiable baseline, accounting for leakage, all to ensure additionality. Much of the attention to carbon inventories can be found in the science literature, for example, Gibbs et al, 2007; Goetz et al., 2009; Keith et al., 2009; Saatchi et al., 2011). Determining credible baseline scenarios requires attention to past rates of forest loss and anticipated future forest loss without REDD, the business as usual baseline, and has proven challenging. Havemann (2009) and Angelsen (2008c) focus their attention on baselines, measuring, and monitoring. These costs are associated with REDD "readiness", and countries have discovered the high set up costs of being able to "monitor, report, and verify" (MRV) the rate of forest loss relative to an unmeasurable counterfactual trajectory of forest loss (Lund et al., 2017). Using data from Laos, Mertz et al. (2017) highlight the costs and difficulties of establishing forest reference levels that are required for payments that reward "avoided" forest loss. Sloan and Pelletier (2012) provide an example of using detailed spatial modelling based on historical trends. Yet forest transitions are rarely linear (Angelsen, 2008a), and indeed Sloan and Pelletier (2012: p441) highlight that "the complexity of forest-cover change renders the reliability of even the 'best' spatially projected baseline indefinite."

Pagiola and Bosquet (2009) similarly explore different dimensions of REDD implementation costs. They highlight the opportunity cost of not converting forest into agricultural land, including loss of a source of timber; implementation costs that include prevention of illegal logging, or the relocation of timber harvesting activities; and transactions costs, that include negotiating contracts, and monitoring, reporting, and verifying emissions reductions. In paying considerable attention to the opportunity cost of REDD Pagiola and Bosquet (2009) 
further show how to build a "national supply curve for REDD." Olsen and Bishop (2009) detail the actual costs to investors of REDD.

\section{On-going costs}

REDD proponents and the literature consistently ignore or undervalue costs of enforcing access restrictions that must be incurred to generate avoided deforestation. Such enforcement requires ongoing expenditure for the life of any REDD project (Börner et al., 2011, 2014). Several situations create particular problems with enforcement costs. First, in settings where forests communities use forests, often with poorly defined de facto rights, the government owner of the land must choose to enforce against that local use or to find mechanisms for the community to receive payments as the incentive. Second, in settings in which the local communities have defined rights and participate in REDD, "outsiders" who traditionally used a now-REDD forest do not share in any REDD payments or associated benefits (Albers and Robinson, 2013; Robinson et al., 2014). REDD implementation requires communities to develop group self-enforcement mechanisms with both upfront transactions costs and ongoing enforcement costs. In addition, the communities face ongoing enforcement costs to prevent outsider extraction in settings with outsiders as important drivers of forest loss or develop mechanisms to share payments with those people to create an incentive for lower forest use. These situations create the potential for costly conflict - an often ignored cost - as some individuals lose access to the forest but are not compensated through the REDD initiative or any other source (Douglas and Simula, 2011; Kane et al. 2017).

Rakatama et al. (2017) provides a comprehensive review of REDD costs for 60 studies. They find that the literature continues to focus on opportunity costs (56 comparable estimates), with less than half the sample addressing transactions and implementation costs, suggesting that the cost effectiveness of REDD projects is thus inflated. Those who have looked for the "hidden costs" of REDD have found them to be high. Alston and Andersson (2011) provide a detailed discussion of further transactions costs of REDD, focusing on negotiating contracts with landowners, monitoring outcomes, and enforcing contracts, which take the mechanism a long way from the Coasean ideal of a PES. Many of these costs must be incurred after a country is "REDD ready". They highlight the costs imposed on LMIC governments with respect to monitoring contractual behavior. Arguably, treating incentives for monitoring, reporting, and verification has proven difficult in part because buyers and sellers of carbon credits have incentives not to monitor closely (see Richards and Andersson, 2001; Alston and Andersson, 2011). Luttrell et al. (2018) consider costs associated with 22 subnational REDD initiatives and the extent to which the costs of implementing REDD borne by those in LMICs outweigh REDD carbon payments. The authors consider start up and running costs, including MRV, free prior informed consent, and enforcement costs, in addition to the direct payment for the ecosystem service. They find that a significant portion of subnational and local institutions incur high costs of REDD+, particularly at the startup phase. Luttrell et al. (2018) further address the institutional motivation behind REDD participation and cost burdening. For example a greater number of implementing organisations will have their costs covered if sustainable forest management and certification are implemented as a core strategy. 
Forest degradation has proven more costly to measure than deforestation, and the counter-factual level of degradation is similarly difficult to determine. As a consequence, some REDD initiatives ignore degradation (monitoring and verification) and focus on deforestation. This was the case for a number of REDD pilots in Tanzania (Robinson et al., 2013, provide detail; see also Gullison et al., 2007; Kindermann et al., 2008).Yet, degradation has been estimated to account for $20 \%$ of forest emissions in Brazil's Amazon forest, around two-thirds of forest loss in Indonesia, and approximately onethird of forest loss in African countries (Murdiyarso et al., 2008).

Ignoring degradation could be more problematic still if reduced deforestation leads to leakage through degradation. In this case leakage may be under-estimated and the impact of REDD on carbon sequestration over-estimated (Delacote and Angelsen, 2015, explore this possibility theoretically). Technological advances have enabled more costeffective remote monitoring of degradation (Thompson et al., 2013 provide an operational framework). However, there has also been increasing recognition of the validity of community-based measurement and assessment of forest degradation (Skutsch et al., 2009; Palmer, 2011).

\subsection{Cost Effectiveness: Additionality and leakage}

For REDD payments to be efficient, they must induce additional carbon storage and the amount of carbon stored must be net of leakage of forest loss to other areas (Gregersen et al., 2010: p1). When a REDD initiative is as a voluntary contract between the government or a private investor and an individual landowner who makes an explicit decision whether or not to convert forest, there will only be an exchange if the payment to the landowner outweighs the various costs of implementing REDD. That central tenet is not enough for efficiency because the payment is inefficient to the extent that the landowner might have conserved the forest without the REDD scheme's incentive; the payment must incentivize additional carbon storage. The empirical literature discusses the extent of additionality. In Costa Rica, where some of the earliest payments for reduced forest loss have been implemented, there was almost no additionality from forest owners (Sanchez-Azofeira et al., 2007; Robalino et al, 2008; Alston and Andersson, 2011).

Leakage is "any additional deforestation, forest degradation, or carbon emissions that occur outside of the REDD policy area in reaction to that REDD policy or project" (Albers and Robinson, 2013: p83). If the activities that were leading to forest loss have merely been displaced elsewhere rather than curtailed, the REDD initiative provides less net reductions in emissions overall. Theoretical analyses identify when and where leakage might occur, focusing in part on the role of markets (for example Robinson et al., 2011). Atmadja and Verchot (2012) provide a review of the empirical realities and practicalities of leakage and REDD across 15 studies, focusing on project-level leakage. They detail four components of leakage, emissions, displacement, attribution, and quantification; two categories, activity and market; and scales of intervention and displacement. They find forest-based leakage from deforestation and degradation to be greater than $40 \%$, but recognize that the number of studies on leakage is small. 
Localised REDD schemes that allow individual and communities to sell carbon credits to an emissions trading scheme are particularly at risk of leakage. In contrast, nationallevel schemes can eliminate at least within country leakage, though leakage across countries is always a possibility. Thus scale of implementation, the method of funding, and leakage are closely linked.

\subsection{Benefits and beneficiaries of REDD}

A classic PES requires well-defined property rights, though following Coase, the allocation of property rights is less important than the definition and enforcement of those rights. For REDD, the distribution of costs and benefits is a critical element of the mechanism, not just for issues of equity and climate justice, but also for anticipating the success of any particular REDD initiative.

\section{The importance of land property rights in REDD}

Property rights institutions influence many aspects of both the efficiency and equity of REDD. First, in the LIMCs where REDD is being implemented, property rights might variously be allocated to national governments, individual landowners, or communities, which create different pathways and obstacles to efficient REDD. In addition, the property rights are frequently ill defined or poorly supported by other institutions. In addition, many people who are harmed by a REDD initiative have no rights to any REDD payments but face much-reduced access to important resources.

"As long as tenure remains insecure, PES programs are very difficult, if not impossible, to implement" (Pagiola, 2011: p8). The need to clarify forest property rights has similarly been recognized by REDD practitioners (for an early but comprehensive discussion of forest tenure rights and REDD, see Sunderlin et al., 2009). Several authors have noted the difficulty of paying individuals for reduced access to forests when that access has been illegal. For example, this aspect of payments has been an issue in Mexico where deforestation is illegal unless the land owner has a land use change permit (Skutsch et al., 2017). In Tanzania, Tanzania Forest Conservation Group has helped villages engaged in REDD pilot projects to apply for village land certificates and establish village land registries to formalize land tenure (Dokken et al., 2014). Yet Sunderlin et al. (2018) assess 21 subnational initiatives across five countries, including Tanzania, and find that only in Cameroon is there evidence that REDD has significantly reduced tenure insecurity, though rarely has it worsened smallholder tenure insecurity.

For REDD, the fact that in many countries the de jure (often the government) and de facto (often local communities) owners or managers of forests differ from each other implies that "ownership is ill-defined, contested, or insecure" (B. Robinson et al., 2014: p281). That communities own, use, or manage forests further complicates property rights definitions. Thus the issue of land tenure and property rights -- who owns the land and the carbon sequestered on that land -- looms large across the REDD literature (e.g. Alston and Andersson, 2011). A review article by B. Robinson et al. (2014), though not focused specifically on REDD, finds 36 publications that link empirically land cover 
change to tenure, and support Sunderlin et al.'s (2014) conclusion that tenure security is particularly important for communities to participate in REDD initiatives.

Efficiency at the Government level can create equity concerns. Whether REDD has reversed efforts of countries to devolve ownership and management of forests to the communities that depend on them has featured large in the REDD literature. Given that REDD strategies are arguably best developed at a national level, a concern is that governments will want to re-assert their control over forests so as to have more control over carbon sequestration. Similarly, the issue of leakage is linked to concerns that REDD might push countries to reverse recent efforts to devolve ownership and management of forests and lead to the recentralization of forest governance (Phelps et al., 2010). Recentralisation of forests can make it easier for governments to implement national REDD programmes, whether through minimising leakage, or using REDD funds to address the drivers of forest loss rather than channelling funds to local forestdependent communities. Linked to this point, REDD can also create the incentive for governments to protect forests at the expense of villagers who have traditionally replied on these forests (Torpey-Saboe et al., 2015).

\section{Benefit sharing at the community level}

Luttrell et al. (2013) place benefit sharing as a central design element of REDD because how payments are allocated determines the required incentives for people to reduce their emissions. Similarly, the issue of property rights becomes more important and complex when implementing REDD at the scale of the community. Palmer (2010) writes explicitly of the need for the creation of "common property carbon rights", given how many REDD initiatives (and planned initiatives) are located in areas where forests are held under common property regimes.

Robinson et al. (2016) document a REDD pilot scheme in Tanzania implemented at the group level to mimic a PES in which payments should be conditional on carbon loss avoided and valued according to prices in the carbon markets. The payment is made to the community, reflecting the value of the avoided carbon emissions, and each member of the community receives an equal share of that payment, regardless of the costs that REDD imposes on that particular individual and on that individual's reduction of forest use. Certainly, some individuals will be harmed differentially by the constraints imposed by the REDD scheme. As such, the approach promotes commitment to a shared and more equitable future rather than to individual incentives for forest use change. Somerville et al. (2010) find in Madagascar that "community-based PES schemes offer a particular challenge, as incentives aimed to influence individual behavior . . . pass through community institutions" (p.1263). Mahanty et al. (2013) assess seven REDD schemes set up as PES, across Africa, Asia, and Latin America, from a total of 44 candidate REDD PES schemes. They find formally recgonised use rights to be sufficient for communities to undertake REDD through a PES agreement in Mexico and Mozambique. However, they also found that upfront and opportunity costs were night compared to the PES payments. Mahanty et al. (2013) document various modalities for how PES funds are distributed within communities, from collective contracts, similar to 
Robinson et al. (2016) example from Tanzania, through to payments to individual contract owners and to community trust funds.

\subsection{Funding REDD}

The complexities of REDD funding, as documented in the literature, are linked to the complexities of implementing REDD (Blom et al., 2010). Two stages of funding have been identified in the literature. The first, funding for "readiness" activities described above almost always relies on public funds, as upfront payments are needed to enable countries and communities to build the needed capacity to be in a position to link funding to verified reductions in emissions and to cover the costs of being REDD ready. The second stage of funding links to the payment for the emissions reductions and the costs of protecting the REDD forests.

The broad financial options to support REDD include fund based, market based, or a mixture of both (Cerbu et al., 2010), with funding linked to the implementation of REDD activities as the basis for a performance-based payments at the national level (Skutsch et al., 2017). Individual lower-income countries would choose how to achieve the contracted amount of reduced forest loss and how to distribute national-level payments, through a mix of national and sub-national level policies. These policies could be ex post performance based or could employ other policies to reduce emissions. The reality has resulted in complex layered approaches, some of which resemble PES and others that do not (Pedroni et al., 2009).

Market-based mechanisms could link forest owners in lower-income countries looking to sell REDD credits with higher-income countries looking to offset their industrial carbon emissions. Yet the emerging reality has been rather different, with very few initiatives able to sell carbon credits (Lund et al., 2017). Indeed, carbon markets have played a very small role in REDD, despite REDD's origins as a market-based mechanism. The European Emissions Trading System, for example, does not accept REDD credits, and other carbon markets may follow suit (Boucher, 2015).

Some REDD pilot projects have explicitly looked to engage directly with carbon markets, including a number of pilots set up by TFCG/MJUMITA in Tanzania (Manyika et al., 2013; Robinson et al., 2013). However, problems with verification of avoided carbon, and the relatively low price of carbon in the voluntary markets, mean that the villages have not been able to trade in the carbon markets and so have relied on dedicated funds that mimic the markets (Vatn et al., 2017). One key concern with regards to funding REDD through carbon markets has been that REDD credits could flood the market and depress the carbon price yet further (Neeff and Ascui, 2009; Skutsch and McCall, 2010). Angelsen et al. (2014) addresses how this risk might be minimized. The reality is, however, that most of the hundreds of REDD projects undertaken so far have been funded through dedicated multilateral and bilateral agreements (Fletcher et al., 2016). 


\subsection{Efficiency, equity, and ancillary benefits}

The choice of funding mechanism is closely linked to the extent to which REDD will generate rents for lower-income countries and particularly communities living near to designated REDD forests, or whether is designed to compensate individuals for the costs that REDD imposes (Karsenty et al., 2014). Thus funding is closely linked to issues of equity and efficiency. If REDD is implemented as a PES, then linking REDD to carbon trading might be a natural next step (for an early discussion, see Laurance, 2008) with efficient funding through an international market for carbon credits with direct payments to forest owners, whether individuals or groups (Angelsen et al., 2012). In such a situation, the forest users would be paid the value of avoided carbon emissions and would engage in such contracts whenever that value more than offsets the cost imposed by fREDD. There have been suggestions that if the only concern for REDD were reduced carbon emissions, then a carbon-efficient REDD would, for example, target commercial farming and ranching in many Latin American countries. Skutch et al., (2017) suggest that the benefits from avoided deforestation in such circumstances are likely to be high, the costs of implementation relatively low, yet such an efficiency focus would direct REDD funds towards relatively richer households in lower-income countries. Alternatively, focusing on reducing deforestation caused by shifting cultivation would be more likely to direct REDD funds towards poorer farmers, but the costs of administering REDD in such circumstances where many smallholder farmers are involved, are likely to be high, suggesting that such a focus could be pro-poor but relatively inefficient (Skutch et al., 2017).

In Tanzania, many REDD projects are being implemented locally through communitybased forest management-type structures. This approach can increase the likelihood of ancillary community benefits. However, REDD could be implemented in government forests designated as important for species and biodiversity conservation, where villagers are already excluded, if imperfectly. In such cases REDD could provide ancillary ecosystem benefits at a relatively low implementation cost (Forest trends, 2009; Robinson et al., 2013).

REDD has been coopted to also improve forest-dependent livelihoods, biodiversity, and to contribute towards sustainable development (Busch et al., 2011; Peterson et al., 2012). However, Phelps et al. (2012) caution that policy makers will face trade offs where high carbon and high biodiversity forests do not overlap geographically (see also Torres et al., 2015). There is scientific evidence that biodiversity conservation is needed if forest carbon stores are to be sustained (Diaz et al., 2009), suggesting the linkages between carbon sequestration and biodiversity are complex.

\section{Future REDD}

The Paris Agreement has "revived attention to REDD" (Sunderlin et al., 2018). Yet in a post-Paris COP world, it is not clear how REDD will evolve, and more broadly, the extent to which or how natural forests will continue to be explicitly included in climate agreements through REDD initiatives. Critiques of REDD are many and varied. Some of the earlier critiques originated from a "moral" stance: should higher-income countries 
be able to offset their emissions with support for lower-income forests through carbon markets. Others highlight objections to the commodification of nature and REDD as a market-based instrument (Fletcher et al., 2016). Other critiques are oriented towards the reality of REDD playing out very differently from the concept, often due to the under-estimation of how costly REDD would be. Still others point to the co-opting of REDD onto the causes of biodiversity conservation, poverty reduction, and sustainable development, thus diluting the original concept that REDD is about climate change and reducing carbon emissions. REDD has been accused of being a "green grab" (Fairhead et al., 2012), an excuse to dispossess local peoples.

Despite these criticisms REDD, most likely, is not dead. However, one can perhaps find in the literature a consensus emerging that REDD is imperfect, imprecise, and implemented in a myriad of ways. Concern has been voiced in the literature that REDD has not lived up to its expectations. Angelsen et al. (2017) suggests that REDD has not delivered the tangible results that were expected of it, and raises important issues with respect to how REDD has evolved over time. The reality of many REDD schemes is that they have moved far from the ideals of a PES scheme, whether with respect to the voluntary aspect of PES, or with respect to the idea that payments are for results rather than effort. For example, Skutsch et al. (2017) propose upfront "fair compensation" as more appropriate than ex post results-based payments.

Many REDD initiatives are occurring at the individual community or forest level, and resemble earlier efforts to protect forests, such as ICDPs, Integrated Conservation and Development Programmes and participatory forest management (Blom et al., 2010). Indeed, though REDD was initially developed explicitly as a carbon mitigation tool that places an economic value on forest carbon sequestration in lower-income countries, REDD, and particularly its manifestation as REDD+ is increasingly conceptualised as in the context of sustainable development (van der Hoff et al., 2015). Turnhout et al. (2017) suggests that a "heterodox REDD+ may provide building blocks for the polycentric governance of the world's remaining tropical forests".

This morphing of REDD away from its initial conceptualization towards a local forest management approach is likely to dilute its impact on climate change and increase the complexity of implementation. It also seems to move REDD far from where efforts to stem forest loss might start from: an understanding of the drivers of forest loss, many of which are external to the forest sector. Most of the attention of REDD, and so the REDD literature, is focused squarely on the forest sector, and much attention is on protecting the sector rather than reducing the external pressures. Robinson et al. (2013) highlight the need to take into account whether the drivers of forest loss are internal or external to a particular forest landscape, when determining the best approach to implementing REDD. If the drivers are external but efforts are focused on a particular set of forests, REDD is in danger of "becom[ing] an enforcement programme that faces similar issues to all previous "fence and fine" deforestation prevention programmes" (Robinson et al., 2013: p142). 


\section{References}

Agrawal, A., Nepstad, D. and Chhatre, A., 2011. Reducing emissions from deforestation and forest degradation. Annual Review of Environment and Resources, 36, pp.373396

Albers, H.J. and Robinson, E.J.Z., 2013. A review of the spatial economics of non-timber forest product extraction: Implications for policy. Ecological Economics, 92, pp.8795.

Albers, H.J. and Robinson, E.J.Z., 2013. Reducing emissions from deforestation and forest degradation. Encyclopedia of Energy, Natural Resource, and Environmental Economics, p.78-85.

Alix-Garcia, J.M., Shapiro, E.N. and Sims, K.R., 2012. Forest conservation and slippage: Evidence from Mexico's national payments for ecosystem services program. Land Economics, 88(4), pp.613-638.

Alston LJ, and Andersson K (2011) Reducing greenhouse gas emissions by forest protection: the transaction costs of implementing REDD. Clim Law 2(2):281-289

Angelsen, A. ed., 2008b. Moving ahead with REDD: issues, options and implications. Cifor.

Angelsen, A. ed., 2009. Realising REDD+: National strategy and policy options. Cifor.

Angelsen, A., 2008a. How do we set the reference levels for REDD payments. In Moving ahead with REDD: issues, options and implications (Vol. 1, pp. 53-64).

Angelsen, A., 2008c. REDD models and baselines. International Forestry Review 10, 465-475.

Angelsen, A., Brockhaus, M., Sunderlin, W.D. and Verchot, L.V. eds., 2012. Analysing REDD+: Challenges and choices. Cifor.

Angelsen, A., Gierløff, C.W., Beltrán, A.M. and den Elzen, M., 2014. REDD credits in a global carbon market: Options and impacts. Nordic Council of Ministers

Atmadja, S. and Verchot, L., 2012. A review of the state of research, policies and strategies in addressing leakage from reducing emissions from deforestation and forest degradation (REDD+). Mitigation and Adaptation Strategies for Global Change, 17(3), pp.311-336

Babiker, M., Reilly, J.M. and Jacoby, H.D., 2000. The Kyoto Protocol and developing countries. Energy Policy, 28(8), pp.525-536.

Blom, B., Sunderland, T. and Murdiyarso, D., 2010. Getting REDD to work locally: lessons learned from integrated conservation and development projects. Environmental science \& policy, 13(2), pp.164-172. 
Borner, J., Wunder, S., Wertz-Kanounnikoff, S., Hyman, G. and Nascimento, N., 2011. REDD sticks and carrots in the Brazilian Amazon: Assessing costs and livelihood implications. CCAFS Working Paper no. 8. CGIAR Research Program on Climate Change, Agriculture and Food Security (CCAFS). Copenhagen, Denmark. Available online at: www.ccafs.cgiar.org

Börner, J., Wunder, S., Wertz-Kanounnikoff, S., Hyman, G. and Nascimento, N., 2014. Forest law enforcement in the Brazilian Amazon: Costs and income effects. Global Environmental Change, 29, pp.294-305.

Boucher, D.H., 2015. The REDD/carbon market offsets debate: big argument, small potatoes. Journal of Sustainable Forestry, 34(6-7), pp.547-558.

Buizer, M., Humphreys, D. and de Jong, W., 2014. Climate change and deforestation: The evolution of an intersecting policy domain. Environmental Science \& Policy, 35: 111.

Cadman, T., Maraseni, T., Ma, H.O. and Lopez-Casero, F., 2017. Five years of REDD+ governance: The use of market mechanisms as a response to anthropogenic climate change. Forest Policy and Economics, 79, pp.8-16

Cerbu, G.A., Swallow, B.M. and Thompson, D.Y., 2011. Locating REDD: A global survey and analysis of REDD readiness and demonstration activities. Environmental Science \& Policy, 14(2), pp.168-180.

Corbera, E., 2012. Problematizing REDD+ as an experiment in payments for ecosystem services. Current Opinion in Environmental Sustainability, 4(6), pp.612-619.

Corbera, E., Estrada, M., May, P., Navarro, G. and Pacheco, P., 2011. Rights to land, forests and carbon in REDD+: insights from Mexico, Brazil and Costa Rica. Forests, 2(1), pp.301-342.

Delacote, P. and Angelsen, A., 2015. Reducing Deforestation and Forest Degradation: Leakage or Synergy?. Land Economics, 91(3), pp.501-515

Díaz, S., Hector, A. and Wardle, D.A., 2009. Biodiversity in forest carbon sequestration initiatives: not just a side benefit. Current Opinion in Environmental Sustainability, 1(1), pp.55-60.

Douglas, J. and Simula, M., 2011. Final Thoughts. In The Future of the World's Forests (pp. 195-207). Springer, Dordrecht

Dyer, N. and Counsell, S., 2010. McREDD: How McKinsey 'cost curves are distorting REDD. Rainforest Foundation Climate and Forests Policy Brief.

Eliasch J. 2008 Eliasch Review - Climate change: Financing global forests. UK O ce of Climate Change www.occ.gov.uk/activities/eliasch.htm (25 Nov. 2008).

Fletcher, R., Dressler, W., Büscher, B. and Anderson, Z.R., 2016. Questioning REDD+ and the future of market-based conservation. Conservation Biology, 30(3), pp.673-675. 
Gibbs, H.K., Brown, S., Niles, J.O. and Foley, J.A., 2007. Monitoring and estimating tropical forest carbon stocks: making REDD a reality. Environmental Research Letters, 2(4), p.045023.

Goetz, S.J., Baccini, A., Laporte, N.T., Johns, T., Walker, W., Kellndorfer, J., Houghton, R.A. and Sun, M., 2009. Mapping and monitoring carbon stocks with satellite observations: a comparison of methods. Carbon balance and management, 4(1), p.2.

Gregersen, H., El Lakany, H., Karsenty, A. and White, A., 2010. Does the opportunity cost approach indicate the real cost of REDD+? Rights and realities of paying for REDD+. Rights and Resources Initiative. Washington DC.

Gullison, R.E., Frumhoff, P.C., Canadell, J.G., Field, C.B., Nepstad, D.C., Hayhoe, K., Avissar, R., Curran, L.M., Friedlingstein, P., Jones, C.D., Nobre, C., 2007. Tropical forests and climate policy. Science, 316(5827): 985-986.

Havemann, T., 2009. Measuring and Monitoring Terrestrial Carbon. The State of the Science and Implications for Policy Makers. The Terrestrial Carbon Group.

Kane, S., Hackman, R., Gritten, D., Luangphay, T. And Phouangmala, B., 2017. Analyzing the enabling environment for transforming forest landscape conflicts: the example of Lao PDR. Responsible Land Governance: Towards An Evidence Based Approach. Annual World Bank Conference on Land and Poverty. Washington DC, March 2017

Karsenty, A., Vogel, A. and Castell, F., 2014. "Carbon rights”, REDD+ and payments for environmental services. Environmental Science \& Policy, 35, pp.20-29

Keith, H., Mackey, B.G. and Lindenmayer, D.B., 2009. Re-evaluation of forest biomass carbon stocks and lessons from the world's most carbon-dense forests. Proceedings of the National Academy of Sciences, 106(28), pp.11635-11640.

Kindermann, G., Obersteiner, M., Sohngen, B., Sathaye, J., Andrasko, K., Rametsteiner, E., Schlamadinger, B., Wunder, S. and Beach, R., 2008. Global cost estimates of reducing carbon emissions through avoided deforestation. Proceedings of the National Academy of Sciences, 105(30), pp.10302-10307.

Laurance, W.F., 2008. Can carbon trading save vanishing forests?. AIBS Bulletin, 58(4), pp.286-287.

Lederer, M., 2011. From CDM to REDD+-What do we know for setting up effective and legitimate carbon governance?. Ecological economics, 70(11), pp.1900-1907.

Long, S., Roberts, E. and Dehm, J., 2010. Climate justice inside and outside the UNFCCC: The example of REDD. The Journal of Australian Political Economy, (66), p.222.

Lund, J.F., Sungusia, E., Mabele, M.B. and Scheba, A., 2017. Promising change, delivering continuity: REDD+ as conservation fad. World Development, 89, pp.124-139. 
Luttrell, C., Loft, L., Gebara, M.F., Kweka, D., Brockhaus, M., Angelsen, A. and Sunderlin, W.D., 2013. Who should benefit from REDD+? Rationales and realities. Ecology and Society, 18(4)

Luttrell, C., Sills, E., Aryani, R., Ekaputri, A.D. and Evinke, M.F., 2018. Beyond opportunity costs: who bears the implementation costs of reducing emissions from deforestation and degradation?. Mitigation and Adaptation Strategies for Global Change, 23(2), pp.291-310.

Mahanty, S., Suich, H. and Tacconi, L., 2013. Access and benefits in payments for environmental services and implications for REDD+: Lessons from seven PES schemes. Land Use Policy, 31, pp.38-47

Mertz, O., Grogan, K., Pflugmacher, D., Lestrelin, G., Castella, J.C., Vongvisouk, T., Hett, C., Fensholt, R., Sun, Z., Berry, N. and Müller, D., 2017. Uncertainty in establishing forest reference levels and predicting future forest-based carbon stocks for REDD+. Journal of Land Use Science, pp.1-15.

Murdiyarso, D., Skutsch, M., Guariguata, M., Kanninen, M., Luttrell, C., Verweij, P. and Martins, O.S., 2008. How do we measure and monitor forest degradation. Moving Ahead with REDD, pp.99-105.

Neeff, T. and Ascui, F., 2009. Lessons from carbon markets for designing an effective REDD architecture. Climate policy, 9(3), pp.306-315.

Oberthür, S. and Ott, H.E., 1999. The Kyoto Protocol: international climate policy for the 21st century. Springer Science \& Business Media.

Okereke, C. and Dooley, K., 2010. Principles of justice in proposals and policy approaches to avoided deforestation: towards a post-Kyoto climate agreement. Global Environmental Change, 20(1), pp.82-95.

Olsen, N., 2009. The financial costs of REDD: evidence from Brazil and Indonesia. IUCN. IN: The Financial Costs of REDD: Evidence from Brazil and Indonesia. Ed. Olsen N. \& Bishop, J. International Union for Conservation of Nature: Gland, Switzerland.

Pagiola, S. and Bosquet, B., 2009. Estimating the costs of REDD at the country level. Forest Corbon Partnership Facility, World Bank.

Pagiola, S., 2011. Using PES to implement REDD. PES Learning Paper 2011-1. World Bank, Washington DC.

Palmer, C., 2011. Property rights and liability for deforestation under REDD+: Implications for 'permanence'in policy design. Ecological Economics, 70(4), pp.571-576.

Palmer, C., Taschini, L. and Laing, T., 2017. Getting more 'carbon bang for your 'buck' in Acre State, Brazil. Ecological Economics, 142, pp.214-227.

Pandit, R., Ma, C. and Iftekhar, S., 2017. The costs and benefits of REDD+: A review of the literature. Forest Policy and Economics, 75, pp.103-111. 
Pedroni, L., Dutschke, M., Streck, C. and Porrua, M.E., 2009. Creating incentives for avoiding further deforestation: the nested approach. Climate Policy, 9(2), pp.207220.

Phelps, J., Webb, E.L. and Adams, W.M., 2012. Biodiversity co-benefits of policies to reduce forest-carbon emissions. Nature Climate Change, 2(7), p.497

Phelps, J., Webb, E.L. and Adams, W.M., 2012. Biodiversity co-benefits of policies to reduce forest-carbon emissions. Nature Climate Change, 2(7), p.497

Phelps, J., Webb, E.L. and Agrawal, A., 2010. Does REDD+ threaten to recentralize forest governance?. Science, 328(5976), pp.312-313

Redford, K.H., Padoch, C. and Sunderland, T., 2013. Fads, funding, and forgetting in three decades of conservation. Conservation Biology, 27(3), pp.437-438.

Richards, K. and Andersson, K., 2001. The leaky sink: persistent obstacles to a forest carbon sequestration program based on individual projects. Climate Policy, 1(1), pp.41-54.

Rights and Resource Initiative (2013). Tenure Trends. Available at https://rightsandresources.org/en/work-impact/tenure-datatool/\#.WtsExNPwYWp [accessed on 21st April 2018]

Robalino, J., Pfaff, A., Sanchez-Azofefia, G.A., Alpízar, F., León, C. and Rodriguez, C.M., 2008. Deforestation impacts of environmental services payments: Costa Rica's PSA program 2000-2005 (No. dp-08-24-efd).

Robinson, B.E., Holland, M.B. and Naughton-Treves, L., 2014. Does secure land tenure save forests? A meta-analysis of the relationship between land tenure and tropical deforestation. Global Environmental Change, 29, pp.281-293.

Robinson, E.J.Z, Albers, H.J. and Williams, J.C., 2011. Sizing reserves within a landscape: The roles of villagers' reactions and the ecological-socioeconomic setting. Land Economics, 87(2), pp.233-249

Robinson, E.J.Z, Albers, H.J., Lokina, R. and Meshack, C., 2016. Allocating group-level payments for ecosystem services: experiences from a REDD+ pilot in Tanzania. Resources, 5(4), p.43

Robinson, E.J.Z, Albers, H.J., Meshack, C. and Lokina, R.B., 2013, August. Implementing REDD through community-based forest management: Lessons from Tanzania. In Natural Resources Forum (Vol. 37, No. 3, pp. 141-152).

Robinson, E.J.Z, Albers, H.J., Ngeleza, G. and Lokina, R.B., 2014. Insiders, outsiders, and the role of local enforcement in forest management: An example from Tanzania. Ecological Economics, 107, pp.242-248

Romano, F. and Reeb, D., 2008. Understanding forest tenure in Africa: opportunities and challenges for forest tenure diversification. Forestry Policy and Institutions Working Paper. Food and Agriculture Organization of the United Nations, Rome. 
Saatchi, S.S., Harris, N.L., Brown, S., Lefsky, M., Mitchard, E.T., Salas, W., Zutta, B.R., Buermann, W., Lewis, S.L., Hagen, S. and Petrova, S., 2011. Benchmark map of forest carbon stocks in tropical regions across three continents. Proceedings of the National Academy of Sciences, 108(24), pp.9899-9904.

Sánchez-Azofeifa, G.A., Harriss, R.C. and Skole, D.L., 2001. Deforestation in Costa Rica: a quantitative analysis using remote sensing imagery. Biotropica, 33(3), pp.378-384

Shrestha, R.M. and Timilsina, G.R., 2002. The additionality criterion for identifying clean development mechanism projects under the Kyoto Protocol. Energy Policy, 30(1), pp.73-79.

Sills, E.O., Atmadja, S.S., de Sassi, C., Duchelle, A.E., Kweka, D.L., Resosudarmo, I.A.P. and Sunderlin, W.D. eds., 2014. REDD+ on the ground: A case book of subnational initiatives across the globe. CIFOR

Skutsch, M.M. and McCall, M.K., 2010. Reassessing REDD: governance, markets and the hype cycle. Climatic Change, 100(3), pp.395-402

Skutsch, M.M., McCall, M.K., Karky, B., Zahabu, E. and Peters-Guarin, G., 2009. Case studies on measuring and assessing forest degradation: community measurement of carbon stock change for REDD. Forest Resources Assessment Programme. Working Paper (FAO).

Sloan, S. and Pelletier, J., 2012. How accurately may we project tropical forest-cover change? A validation of a forward-looking baseline for REDD. Global Environmental Change, 22(2), pp.440-453.

Sommerville, M., Jones, J.P., Rahajaharison, M. and Milner-Gulland, E.J., 2010. The role of fairness and benefit distribution in community-based Payment for Environmental Services interventions: A case study from Menabe, Madagascar. Ecological Economics, 69(6), pp.1262-1271.

Stern, N., 2007. Stern Review: The Economics of Climate Change. H.M. Treasury, London.

Sunderlin, W.D., de Sassi, C., Sills, E.O., Duchelle, A.E., Larson, A.M., Resosudarmo, I.A.P., Awono, A., Kweka, D.L. and Huynh, T.B., 2018. Creating an appropriate tenure foundation for REDD+: The record to date and prospects for the future. World Development, 106, pp.376-392

Sunderlin, W.D., Hatcher, J. and Liddle, M., 2008. From exclusion to ownership? Challenges and opportunities in advancing forest tenure reform. Rights and Resources Initiative.

Sunderlin, W.D., Larson, A.M., Duchelle, A.E., Resosudarmo, I.A.P., Huynh, T.B., Awono, A. and Dokken, T., 2014. How are REDD+ proponents addressing tenure problems? Evidence from Brazil, Cameroon, Tanzania, Indonesia, and Vietnam. World Development, 55, pp.37-52. 
Thompson, I.D., Guariguata, M.R., Okabe, K., Bahamondez, C., Nasi, R., Heymell, V. and Sabogal, C., 2013. An operational framework for defining and monitoring forest degradation. Ecology \& Society, 18(2).

Torpey-Saboe, N., Andersson, K., Mwangi, E., Persha, L., Salk, C. and Wright, G., 2015. Benefit sharing among local resource users: the role of property rights. World Development, 72, pp.408-418.

Van der Hoff, R., Rajão, R., Leroy, P. and Boezeman, D., 2015. The parallel materialization of REDD+ implementation discourses in Brazil. Forest Policy and Economics, 55, pp.37-45.

Van der Werf, G.R., Morton, D.C., DeFries, R.S., Olivier, J.G., Kasibhatla, P.S., Jackson, R.B., Collatz, G.J. and Randerson, J.T., 2009. CO 2 emissions from forest loss. Nature geoscience, 2(11), p.737.

Vatn, A., Kajembe, G., Mosi, E. and Nantongo, M., 2017. What does it take to institute REDD+? An analysis of the Kilosa REDD+ pilot, Tanzania. Forest Policy and Economics, 83, pp.1-9.

Wunder, S. 2005 Payments for environmental services: some nuts and bolts. CIFOR Occasional Paper No. 42. CIFOR, Bogor, Indonesia. 24p.

Wunder, S., 2009. Can payments for environmental services reduce deforestation and forest degradation. Realising REDD, p.213 